\title{
The role of open innovation and absorptive capacity in innovation performance: Empirical evidence from Slovenia*
}

Kaja Rangus, Mateja Drnovšek, Alberto Di Minin, André Spithoven ${ }^{* *}$

\begin{abstract}
Although research on open innovation practices in larger and smaller organisations has been growing for over a decade, there has been limited evidence on the topic related to new and candidate members of the European Union. Existing studies of open innovation have predominantly focused on the examination of the phenomenon in companies from the most developed European countries (i.e. EU15). In this research, we examine how absorptive capacity and open innovation interact to impact innovation performance, based on a large dataset of companies operating in Slovenia. We contribute to the literature on open innovation by showing how an organisation's capacity for open innovation can be used to its full potential in order to impact the firm's performance.
\end{abstract}

Obwohl die Forschung zu Praktiken der Open Innovation („offene Innovation“) in größeren und kleineren Unternehmen seit mehr als einem Jahrzehnt wächst, gibt es nur spärliche Evidenzen zum Thema in Bezug auf die neuen Mitgliedsstaaten der Europäischen Union und bei Ländern, die auf den Beitritt zur EU kandidieren. Vorhandene Studien zu Open Innovation konzentrieren sich vornehmlich auf die Untersuchung des Phänomens in Unternehmen der europäischen Länder, die am meisten entwickelt sind (z.B. EU15). In dieser Forschungsarbeit untersuchen wir, basierend auf dem großen Datensatz von Unternehmen, die in Slowenien operieren, wie Absorptionsfähigkeit und Open Innovation bei der Wirkung auf Innovationsleistungen interagieren. Wir leisten einen Beitrag zur Literatur über Open Innovation, indem wir zeigen, wie die Kapazität eines Unternehmens für Open Innovation in ihrem ganzen Potenzial bei der Wirkung auf die Leistungsfähigkeit einer Firma genutzt werden kann.

Keywords: Open innovation, absorptive capacity, innovation performance, organisational capabilities,

JEL O31, JEL O32

\section{Introduction}

Open innovation can be considered to be one of the most relevant concepts in innovation management (Huizingh 2011), having occupied the limelight since Chesbrough's (2003) seminal work. The main idea of open innovation is to open up the innovation process to other firms, individuals, research labs, universities, customers, suppliers, and so on (Chesbrough 2006) in order to facilitate the

* Manuscript received 29.08.2014, accepted 23.12.2015 (2 revisions)

** Kaja Rangus, PhD. , Brodarjev trg 15, 1000 Ljubljana, Slovenia, Faculty of Economics, University of Ljubljana, E-mail: kaja.rangus@ef.uni-lj.si

Prof. Mateja Drnovšek, PhD., Faculty of Economics, University of Ljubljana, E-mail: mateja.drnovsek@ef.uni-lj.si

Assoc. Prof. Alberto Di Minin, PhD., Scuola Superiore Sant'Anna, Pisa, E-mail: a.diminin@sssup.it

André Spithoven, PhD., Belgian Science Policy Office and Ghent University, E-mail: andre.spithoven@belspo.be

JEEMS, 22 (1) 2017, 1-3

DOI: 10.5771/1862-0019-2017-1-1 
smooth flow of ideas inside and outside of the organisation. In doing so, the organisation derives advantages from both the exploration of external resources and the exploitation of internal resources (Chesbrough 2003). Existing research has focused on open innovation practices in developed economies (e.g. Laursen/ Salter 2006; van de Vrande et al. 2009; Spithoven 2013), offering only scarce evidence on less developed countries, such as the ex-socialist countries. Although Western European firms have operated as exemplars for those in transition economies, these economies have encountered some difficulties in organisational restructuring due to cultural barriers (Mikl-Horke 2004). For example, intra-organisational opening processes, in terms of dialogical leadership, employee interaction, and critical upward communication, are the logical extensions of the processes of privatisation and deregulation; however, these processes are uncommon for the traditional mindset of closed societies (Tünde/Gebert 2005).

Given the role played by innovation in ensuring organisational competitiveness (Hurley/Hult 1998), it is important to understand the specificities of open innovation in companies competing in less developed markets. The intense transformation from a closed to an open market economy impeded not only these companies' economic performance, but also their innovative capacities (Krammer 2009). These countries were generally isolated from the flows of trade and the ideas of developed Western countries. Consequently, they failed to follow the latest technological breakthroughs (Murrell 1990). In light of these differences, Central and Eastern European countries provide an interesting basis for testing the generalisability of existing theories and for identifying hidden features and assumptions that often go unnoticed when conducting research on mature market economies. Indeed, the transition processes provide the opportunity for a series of unique societal quasi-experiments (Meyer/Peng 2005). In this research, we explore open innovation in companies from an ex-socialist economy. In particular, the study is based on rich data drawn from a large set of companies in Slovenia. Slovenia makes a good case country, since it is a small transition economy that has outperformed other countries in this region in terms of national innovation performance (European Commission 2015).

Existing studies on open innovation in Slovenia have revealed that, for the past few years, Slovenia has been developing a business environment that is friendlier towards open innovation (Krapež et al. 2012). In 2011, preliminary evidence on the state of open innovation in Slovenia among high-tech companies showed that $33 \%$ of the surveyed companies were inclined to open innovation (Rašković et al. 2011). Larger companies were more involved in open innovation activities, and there was a general trend towards opening up the innovation process (Rangus/Drnovšek 2013). These findings are aligned with those from research on open innovation in other European countries (e.g. van de Vrande et al. 2009; Schroll/Mild 2011). Similarly, the absorptive capacity of Slovenian companies in relation to the firm's innovation performance seems to be comparable to com- 
panies in developed economies. Indeed, the $2.16 \%$ research and development (R\&D) intensity of the Slovenian business sector is well above the European Union (EU) level of $1.31 \%$ (European Commission 2015). As R\&D expenditure (the numerator of R\&D intensity) is often seen as the prime proxy for absorptive capacity, Slovenia is a good case country for the new EU member states and those in the process of EU accession.

Therefore, we argue that analysing innovation performance in terms of the new concepts of open innovation and absorptive capacity on a sample of companies from Slovenia may offer noteworthy implications for those competing in less developed markets. In doing so, we contribute to the cumulative body of knowledge on open innovation by examining the organisational correlates through which open innovation impacts a firm's innovation performance. We provide theoretical and empirical grounds for addressing central questions regarding innovation management research, such as: how does open innovation influence a firm's absorptive capacity and innovation performance; and how do absorptive capacity and open innovation interact to impact innovation performance? By examining open innovation and absorptive capacity in parallel, we contribute to the current literature on how dynamic capabilities operate in combination with one another (Ambrosini/Bowman 2009).

\section{Theoretical background and hypotheses development}

The overall theoretical foundations of our conceptual model are grounded in the dynamic capabilities perspective (Teece et al. 1997; Eisenhardt/Martin 2000; Teece 2007), which emerged from the resource-based view (Barney 1986, 1991). Valuable, rare, imperfectly imitable, and non-substitutable resources ensure an organisation's sustained competitive advantage (Barney 1991). Additional sources of competitiveness are network resources, which are accessible to organisations that secure regular collaborations with various partners in their contextual environments (Lavie 2006). The major drivers of open innovation are resources and capabilities, which nurture R\&D projects and allow them to be developed into new business products over time (Vanhaverbeke/Cloodt 2014).

In a turbulent environment, resources cannot stay stable and simultaneously persist on value; they must constantly progress and develop in order to remain competitive (Ambrosini/Bowman 2009). Dynamic capabilities identify, shape, and seize technological and market opportunities (Teece 2007), and are defined as the "firm's ability to integrate, build, and reconfigure internal and external competences to address rapidly changing environments" (Teece et al. 1997:516). The three sources of dynamic capabilities are (1) the capability to sense and shape opportunities and threats, (2) the capability to seize opportunities, and (3) the capability to maintain competitiveness through enhancing, combining, protecting, and, when necessary, reconfiguring the business enterprise's intangible 
and tangible assets (Teece 2007:1319). In other words, they refer to a "firm's processes that use resources to integrate, reconfigure, gain and release resources to match and even create market change" (Eisenhardt/Martin 2000:1107).

The ideas of scanning, searching, and exploring across technologies and markets, reaching out and involving external partners, and connecting internal and external resources with an aim to consolidate a competitive position in a constantly changing environment are also central to open innovation (Chesbrough 2003). Drawing on the existing literature on dynamic capabilities, open innovation is seen as an important element of a firm's dynamic capability (Teece 2007). Gassmann (2006) distinguished several types of open innovation activities, outside-in and inside-out. Outside-in open innovation deals with acquiring external resources. Activities that facilitate the engagement of external resources involve interaction with customers, networking, external participation, outsourcing of R\&D, and inward IP licensing (van de Vrande et al. 2009). In general, inside-out activities enable the firm to leverage multiple paths to market (Chesbrough 2003). Inside-out open innovation activities are more aimed at the outward licensing of intellectual property (IP) (van de Vrande et al. 2009). Moreover, the potential of internal resources can be maximised through open innovation activities, such as venturing and employee involvement.

Absorptive capacity has been recognised as an important component of a firm's dynamic capabilities, as it enables firms to learn from partners, access external information, and transform and integrate that information into its existing knowledge base (Wang/Ahmed 2007). Organisations with a high level of absorptive capacity have superior capabilities for targeting, absorbing, and deploying new knowledge, which, in turn, facilitates internal innovation activities (Fosfuri/Tribó 2008).

We have developed a conceptual model of the effects of open innovation and absorptive capacity on innovation performance (Figure 1). The model is grounded in the resource-based view, the dynamic capabilities perspective, open innovation research, and prior research on absorptive capacity. The processes in the model are triggered when open innovation is activated, engaging the exploration of external resources and the exploitation of internal resources. Open innovation, thus, regulates organisational efforts for successful innovation performance. We suggest that open innovation leads to increased innovation performance both directly (path A in Figure 1) and indirectly (path B/C in Figure 1) through absorptive capacity. Below, we review the theoretical arguments that shed light on each proposed path in the model. 
Figure 1: The mediation effect of absorptive capacity on the relationship between open innovation and innovation performance

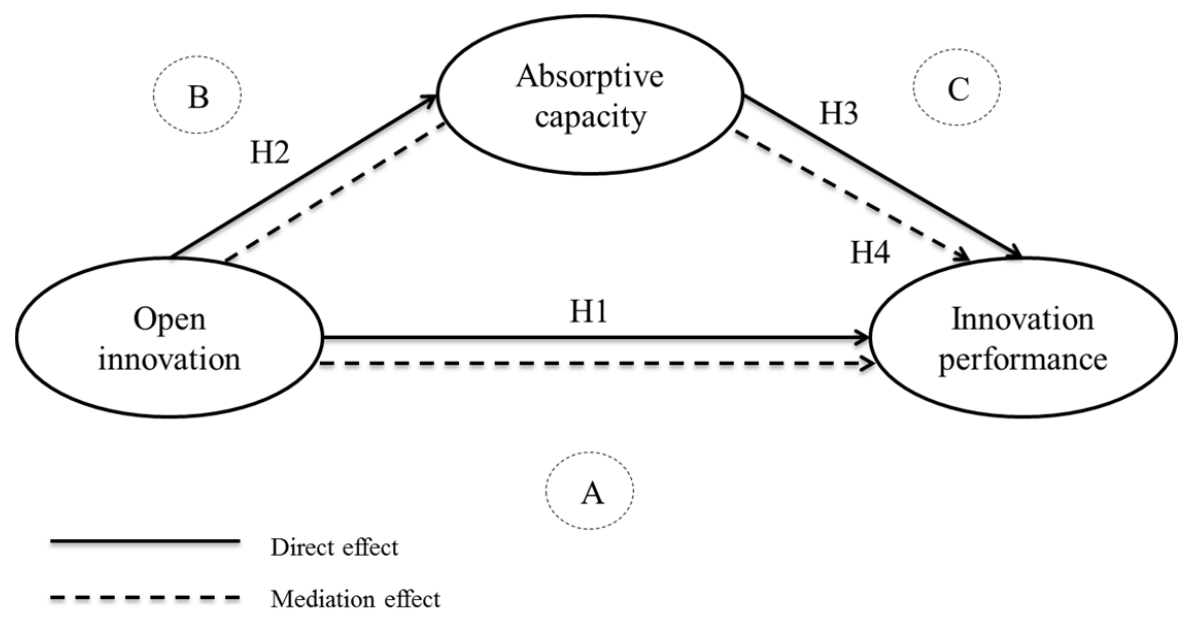

\subsection{Direct effects of open innovation on the innovation performance of a firm}

We hypothesise that open innovation has a direct positive effect on innovation performance (path A in Figure 1). Prior literature has suggested that organisations can improve their innovation performance by incorporating inbound and/or outbound open innovation activities (Chesbrough/Crowther 2006). Open innovation is a multidimensional construct that involves outsourcing $R \& D$, external networking, customer involvement, inward IP licensing, external participation, employee involvement, and venturing-related activities (van de Vrande et al. 2009; Rangus et al. 2013). As we use a measure of open innovation that takes all of these dimensions into account, we discuss mechanisms that connect each specific dimension of open innovation to a firm's innovation performance.

As far as external networking is concerned, prior research has suggested that organisations with a greater number of external search channels possess a superior capability to sustain exchange and collaboration with external partners. In turn, they have access to more innovative opportunities, which positively impacts a firm's innovation performance (Laursen/Salter 2006) and results in market push innovations. Furthermore, customers provide ideas on how to improve existing products and services in order to better address their needs. These contributions have been shown to positively affect a firm's innovation performance (Chesbrough, 2003). When collaborating with universities, organisations access new technological and scientific capabilities through the specialised and expert knowledge of scientists. Enhanced technological and scientific capabilities have 
been shown to have positive effects on innovation performance (Fabrizio 2006). Furthermore, when such collaborations are formalised (e.g. in the form of a joint venture), the resulting patenting activity also increases (Santamaría et al. 2009). This improves organisational performance, because IP in-licensing saves time and money and offers access to validated technologies that in turn facilitate the development of more complex products (Tao/Magnotta 2006). Employee involvement likewise facilitates innovation performance by leveraging the knowledge and initiatives of employees not involved in the R\&D process (van de Vrande et al. 2009). Searching for patentable ideas both inside and outside the firm's boundaries (Chesbrough 2003) and collaborating across divisions within the organisation enable the sharing and borrowing of ideas (O'Connor 2005). Finally, a firm's innovation performance can be enhanced through venturing activities to commercialise internal technological capabilities (van de Vrande et al. 2009). In doing so, organisations enter new markets and industries (Block/ MacMillan 1995), and gain access to information about future technologies and market opportunities (Chesbrough 2003), which have been shown to improve innovation performance.

Based on the arguments presented above, we propose the following hypothesis:

Hypothesis 1: There is a direct positive relationship between open innovation and the innovation performance of a firm.

\subsection{The mediating effects of absorptive capacity}

Open innovation enhances a firm's innovation performance because it facilitates the building of absorptive capacity. In support of the mediating effect of absorptive capacity on the relationship between open innovation and a firm's innovation performance, we first provide evidence to support the direct effect of open innovation on absorptive capacity (path B in Figure 1), followed by arguments supporting the positive impact of absorptive capacity on innovation performance (path C in Figure 1).

Open innovation enhances organisational absorptive capacity (Tether/Tajar 2008). Studies have shown that drivers of absorptive capacity involve interaction with external knowledge sources, such as licensing and contractual agreements, and collaboration with different partners, including R\&D consortia, alliances, and joint ventures (Zahra/George 2002) - all of which are dimensions of open innovation. The greater the interaction with external sources, the more experiential knowledge is collected with respect to the management of external information. Interaction among employees implies knowledge sharing and an escalation of their learning abilities (Liao et al. 2007). When this logic is applied at firm level, we suggest that interaction with different partners enables organisa- 
tions to acquire new knowledge that develops and increases their learning abilities. This leads us to propose the following:

Hypothesis 2: There is a direct positive relationship between open innovation and absorptive capacity.

In turn, because firms with higher levels of absorptive capacity possess superior capabilities to apply new knowledge to commercial ends, higher levels of absorptive capacity lead to better innovation performance (Tsai 2001). Absorptive capacity enables firms to identify and exploit specific technological knowledge and to gain first-mover advantage in exploiting new technologies (Cohen/ Levinthal 1989). Applying Tsai's (2001) logic of a firm's unit-level absorptive capacity to the organisational level, organisations with higher levels of absorptive capacity can better harness and transfer new knowledge from external partners and better absorb new inputs to generate innovation performance-related outputs. These arguments lead us to propose the following:

Hypothesis 3: There is a direct positive relationship between absorptive capacity and a firm's innovation performance.

Based on our discussion of the direct effect of open innovation on a firm's innovation performance and the direct effect of absorptive capacity on innovation performance, we propose the following:

Hypothesis 4: Absorptive capacity mediates the relationship between open innovation and a firm's innovation performance.

\section{Methodology and data analysis}

\subsection{Sampling and data collection}

To gather data for the empirical analysis of the proposed conceptual model, we randomly selected 2,000 Slovenian manufacturing and service firms from the Business Directory of the Republic of Slovenia (PIRS) and emailed the survey instrument to the top executives of the firms in May 2013. The survey invitation was sent using the names and email addresses of those listed in the PIRS as the CEO or responsible person of the selected firms. To ensure enough responses, we sent the first reminder after a week and another one after three weeks. We received 428 responses $(21.4 \%$ response rate); seven questionnaires were excluded due to a high proportion (i.e. more than $20 \%$ ) of missing data. The valid response rate was thus $21.1 \%$. The majority $(92.9 \%)$ of respondents indicated that they were part of the top management team of the company. We collected data from a wide range of industries - the majority from manufacturing, information and communication, and services. Table 1 presents the composition of the companies in our sample and of the total population of companies in Slovenia in terms of firm size and industry. 
Table 1: Sample composition

\begin{tabular}{lcc}
\hline & $\begin{array}{c}\text { Slovenian } \\
\text { sample }\end{array}$ & Slovenian population \\
\hline FIRM SIZE & $33.3 \%$ & $95.0 \%$ \\
Micro (0-9 employees) & $46.6 \%$ & $3.7 \%$ \\
Small (10-49 employees) & $11.9 \%$ & $1.1 \%$ \\
Medium (50-249 employees) & $8.2 \%$ & $0.2 \%$ \\
Large (250 employees or more) & & \\
& & \\
FIRM INDUSTRY & $2.8 \%$ & $1.6 \%$ \\
Agriculture and mining & $29.0 \%$ & $10.3 \%$ \\
Manufacturing sector & $44.9 \%$ & $52.6 \%$ \\
Service sector & $11.2 \%$ & $11.1 \%$ \\
Construction & $12.1 \%$ & $27.6 \%$ \\
Public sector & & \\
\hline
\end{tabular}

As Table 1 shows, the sample deviates somewhat from the entire population of Slovenian firms. The overrepresentation (in the sample) of larger firms active in specific industries, such as manufacturing, is due to the nature of innovation itself. First, as we know from the recurring results of the well-known Community Innovation Surveys (CIS), not all firms engage in innovation activities. Second, the prominence of innovation among larger firms has been well-documented in an extensive body of empirical literature. The involvement of larger firms is even more pronounced in the case of open innovation, as exemplified by case study research (e.g. Dodgson et al. 2006; Huston/Sakkab 2006). The reason for this increased involvement is that larger firms have more bargaining power than smaller firms (Dooley et al. forthcoming). A similar argument applies to the overrepresentation of firms active in the manufacturing sector. Since the beginning of the innovation studies field, the focus has been on technological innovation in terms of well-defined products and processes that are more easily identifiable (and, therefore, measurable) in the manufacturing sector (see e.g. Laursen/ Salter 2006). Furthermore, the manufacturing sector has been found to be more innovative (or $R \& D$ intensive) than the service sector, although recent evidence suggests their convergence (Bogliacino/Pianta forthcoming). Hence, our sample is not representative of the Slovenian population of firms, but rather the Slovenian population of innovative firms.

Slovenia was chosen from among other new EU member countries due to its outstanding innovation performance evident in the Innovation Union Scoreboard 2015. Out of all of the new member states and EU candidate countries, Slovenia's innovation performance is closest to that of the "old" EU members. According to the most recent European Commission report (2015), Slovenia is the 
fastest growing country $(2.6 \%)$ among the "innovation followers" in terms of its innovation index. The relative strength of the Slovenian innovation system is due to its high $R \& D$ expenditures, which contribute to building absorptive capacity, and its co-publications (both international scientific and public-private), which ensure a solid knowledge flow throughout the innovation system (European Commission 2015).

For the purpose of this research, a survey instrument was developed that included validated scales of open innovation, absorptive capacity, a firm's innovation performance, and technological turbulence (control variable). All measures were adopted from prior research. We tested their validity and reliability in the context of our empirical sample. We used Dillman et al.'s (2009) tailored design method for the questionnaire development, and employed a translation and back translation method for translating the questionnaire (from English to Slovenian and back to English) in order to ensure the international equality of the items. The questionnaire was pretested on a sample of 20 CEOs from different Slovenian firms in order to collect their feedback on the items and their experience of completing the questionnaire.

\subsection{Measures}

Open innovation. Open innovation was measured using the proclivity for open innovation scale developed and tested by Rangus et al. (2013) (see Appendix for scale items). The multidimensional measure has been cross-culturally validated and consists of five dimensions (external participation and inward IP licensing, outsourcing R\&D and external networking, customer involvement, employee involvement, and venturing) with 22 corresponding items on a 7-point Likert scale (e.g. $1=$ strongly disagree $; 7=$ strongly agree) .

Absorptive capacity. We used a scale developed by Kotabe et al. (2011) for measuring absorptive capacity (see Appendix). The scale consists of nine items and measures a firm's realized absorptive capacity, reflecting knowledge transformation and exploitation. Respondents indicated on a 7-point Likert scale how strong they disagreed/agreed with the statements.

Innovation performance. Our key dependent variable innovation outcome was measured with six items related to product and process innovation from Jiménez-Jiménez and Sanz-Valle's (2011) innovation scale (see Appendix). To minimise bias from subjective answers, we followed the recommendations of Kraft (1990) and asked respondents to evaluate the company's innovation performance against the major competitors in their industry over the previous three years. They recorded their responses on a 7-point Likert scale ranging from much worse than competitors to much better than competitors. When using measures compared to competitors, the level of competition becomes as disaggregated as possible; responding companies were asked to define their relevant market 
themselves in order to measure the perceived degree of competitive pressure at firm level (Kraft 1990). Table 2 presents the means and standard deviations of the manifest variables.

Table 2: Means and standard deviations of the manifest variables

\begin{tabular}{lcc}
\hline & Mean & Std. Deviation \\
\hline $\begin{array}{l}\text { OI: Inward IP licensing and ex- } \\
\text { ternal participation }\end{array}$ & 4.92 & 1.29 \\
OI: Outsourcing R\&D and ex- & & 1.22 \\
ternal networking & 2.80 & 1.20 \\
OI: Customer involvement & & 1.12 \\
OI: Employee involvement & 5.47 & 1.22 \\
OI: Venturing & 5.56 & 1.13 \\
Absorptive capacity 1 & 5.51 & 1.15 \\
Absorptive capacity 3 & 5.91 & 1.17 \\
Absorptive capacity 4 & 5.93 & 1.04 \\
Absorptive capacity 5 & 5.83 & 1.13 \\
Absorptive capacity 6 & 6.13 & 1.09 \\
Absorptive capacity 7 & 5.94 & 1.13 \\
Absorptive capacity 9 & 5.87 & 1.32 \\
Innovation performance 1 & 5.88 & 1.42 \\
Innovation performance 2 & 4.95 & 1.33 \\
Innovation performance 3 & 5.04 & 1.27 \\
Innovation performance 4 & 5.00 & 1.40 \\
Innovation performance 5 & 4.84 & 1.25 \\
Innovation performance 6 & 4.77 & \\
\hline & 4.66 & \\
\hline
\end{tabular}

Note. $\mathrm{OI}=$ Open innovation

We excluded the second and eighth item of absorptive capacity due to high VIF values.

Control variables. Seven control variables were included in the model. At industry level, we controlled for technological turbulence, which has been shown to influence innovation performance (Zhou et al. 2005). We used Jaworski and Kohli's (1993) scale for measuring technology turbulence, i.e. the extent to which technology changes in the industry (see Appendix). At the firm level, we controlled for firm size (measured as a construct composed of three variables: a logarithm of the number of employees, a logarithm of total assets, and a logarithm of total sales), firm industry (agriculture and mining, manufacturing sector, service sector, construction, and public sector), firm age (young vs. old), ownership (if the respondent was an owner or co-owner of the company), respondent's job position (CEO, Head of R\&D, or Other), and firm R\&D investment (the percentage of R\&D investments in terms of total sales). 


\subsection{Data analyses}

We first analysed data to determine whether the missing data displayed a pattern. Little's MCAR test showed that data were missing entirely at random (Hair et al. 2010). The highest proportion of missing data per response was $6.4 \%$, whereas all others were below $3 \%$. Because of the low percentage of missing data, the data were replaced using the expectation-maximisation method, which provides the least bias under conditions of random missing data (Hair et al. 2010).

To minimise the problem of common method bias, we followed the steps recommended by Podsakoff et al. (2003) and took precautionary measures early on in the process of designing the study. We also performed Harman's single-factor test, wherein an unrotated factor analysis resulted in a five-factor solution accounting for $73.1 \%$ of total variance (factor 1 accounted for $33.0 \%$ of the variance). Moreover, we employed the one-factor test using confirmatory factor analysis (CFA). Common method variance poses a serious threat if a simple model (such as a single-factor model) fits the data well (Korsgaard/Roberson 1995). The results of the CFA showed that the model with the single factor did not fit the data well $($ Chi-Square $/ \mathrm{df}=17.22 ; \mathrm{RMSEA}=0.23 ; \mathrm{NFI}=0.72 ; \mathrm{NNFI}=0.70$; $\mathrm{CFI}=0.73 ; \mathrm{IFI}=0.73$; $\mathrm{SRMR}=0.17$; GFI $=0.47$; $\mathrm{AGFI}=0.36$, whereas the null model containing five factors yielded a much better fit (Chi-Square/df $=$ 4.69; RMSEA $=0.10 ; \mathrm{NFI}=0.92 ; \mathrm{NNFI}=0.93 ; \mathrm{CFI}=0.94 ; \mathrm{IFI}=0.94 ; \mathrm{SRMR}$ $=0.22 ; \mathrm{GFI}=0.79 ; \mathrm{AGFI}=0.76$ ). Although these procedures do not exclude the possibility of common method variance, indicators suggested that, in the context of this study, common method variance was not of great concern (Korsgaard/ Roberson 1995).

We checked for late-response bias, comparing early and late responses on firm industry and total sales, and found no significant differences. We also tested for multicollinearity problems, calculating variance inflation factors (VIF). Due to high VIF values, we excluded two items from the construct of absorptive capacity. The excluded items were: "We have the capability to develop new products/ services by using assimilated new knowledge"; "We have the capability to introduce product/service innovation based on acquired new knowledge."

Before testing the hypothesised relationships, we performed CFA and tested for the convergent and discriminant validity of the constructs using Lisrel 8.80 software. We checked the internal consistency of the constructs using Cronbach's alphas (calculated using IBM SPSS Statistics 20). The two factors of product and process innovation proved highly correlated; therefore, we used innovation as a one-factor construct.

Since open innovation is a second-order construct, we performed all of the analyses for this construct first. Convergent validity was supported, as all factor 
loadings were highly significant and the $t$-values were well in excess of 2.58 in absolute terms. The Cronbach's alphas of the five factors of the open innovation construct ranged from 0.721 to 0.848 . The average variance extracted (AVE) varied from 0.479 to 0.594 , and the discriminant validity of the construct was supported, since the AVEs of the factors were larger than the shared variance between the factors. The results also supported the acceptable fit of the model $($ Chi-Square/df $=3.04 ;$ RMSEA $=0.07 ; \mathrm{NFI}=0.93 ; \mathrm{NNFI}=0.95 ; \mathrm{CFI}=0.95$; $\mathrm{IFI}=0.95 ; \mathrm{SRMR}=0.06 ; \mathrm{GFI}=0.90 ; \mathrm{AGFI}=0.86$ ). However, with the aim of reducing the amount of data, we used summated scales for building the construct of open innovation. The Cronbach's alpha of the construct was 0.710 . The convergent validity of the other three constructs (absorptive capacity, innovation performance, and technological turbulence) was also supported; the standardised loadings of all measurement items were highly significant, with the smallest $t$ value being 17.23. The Cronbach's alphas of the constructs were as follows: absorptive capacity $=0.945$; innovation $=0.929$; technological turbulence $=0.896$. Standardised loadings of the variables are presented in the Appendix. The results of the AVE and shared variance (presented in Table 3) generally supported the convergent and discriminant validity among the constructs. Correlations among the constructs are presented in Table 4.

Table 3: Average variance extracted and shared variance

\begin{tabular}{lccccc}
\hline & 1 & 2 & 3 & 4 & 5 \\
\hline 1. Open innovation & 0.34 & & & & \\
2. Absorptive capacity & 0.20 & 0.71 & & & \\
3. Innovation & 0.39 & 0.31 & 0.69 & & 0.76 \\
4. Technological turbulence & 0.08 & 0.12 & 0.21 & 0.81 \\
5. Firm size & 0.01 & 0.01 & 0.03 & 0.01 & 0.01 \\
\hline
\end{tabular}

Note. The numbers on the diagonal show average variance extracted.

Table 4: Correlation matrix

\begin{tabular}{lccccccc}
\hline & Mean & $S D$ & 1 & 2 & 3 & 4 & 5 \\
\hline 1. Open innovation & 4.85 & 0.82 & 1.00 & & & & \\
2. Absorptive capacity & 5.93 & 0.97 & 0.63 & 1.00 & & & \\
3. Innovation & 4.88 & 1.14 & 0.56 & 0.45 & 1.00 & & \\
4. Technological turbulence & 5.05 & 1.49 & 0.46 & 0.29 & 0.35 & 1.00 & \\
5. Firm size & 4.48 & 0.67 & 0.18 & 0.12 & 0.12 & 0.08 & 1.00 \\
\hline
\end{tabular}

\section{Results}

We tested the hypothesised relationships using Lisrel 8.80. We performed three tests to check for the mediation effect of absorptive capacity. We first employed 
a step-by-step inclusion of the paths to determine the best fitting model. Second, we employed the Sobel, Aroian, and Goodman tests, and, finally, we followed the steps recommended by Baron and Kenny (1986).

The results suggested that the proposed model with the mediation effect represented a good model fit $($ Chi-Square $/ \mathrm{df}=3.48$, RMSEA $=0.08, \mathrm{NFI}=0.95$, $\mathrm{NNFI}=0.96, \mathrm{CFI}=0.96, \mathrm{IFI}=0.96, \mathrm{SRMR}=0.06, \mathrm{GFI}=0.85, \mathrm{AGFI}=0.81$ ). The null model with no relations between the constructs had a significantly poorer fit than alternative models. Table 5 presents the results of the proposed and alternative models.

Table 5: Goodness of fit statistics for step-by-step analyses

\begin{tabular}{lccc}
\hline & Model 0 & Model 1 & Model 2 \\
\hline$\chi^{2}$ & 1180.68 & 834.60 & 848.30 \\
DF & 252 & 242 & 244 \\
RMSEA & 0.10 & 0.08 & 0.08 \\
NFI & 0.92 & 0.95 & 0.95 \\
NNFI & 0.93 & 0.96 & 0.96 \\
CFI & 0.94 & 0.96 & 0.96 \\
IFI & 0.94 & 0.96 & 0.96 \\
SRMR & 0.22 & 0.06 & 0.06 \\
GFI & 0.79 & 0.85 & 0.85 \\
AGFI & 0.76 & 0.81 & 0.81 \\
\hline
\end{tabular}

The results supported Hypothesis 1, which proposed a direct positive relationship between open innovation and innovation performance $(\beta=0.47, p<0.001)$. Hypothesis 2, which suggested that there would be a relationship between open innovation and absorptive capacity $(\beta=0.63, p<0.001)$, and Hypothesis 3 , which proposed the positive effect of absorptive capacity on innovation performance $(\beta=0.17, p<0.01)$, were also supported. Moreover, the results of the Sobel, Aroian, and Goodman tests supported Hypothesis 4, which predicted that absorptive capacity would mediate the relationship between open innovation and innovation performance $(\beta=0.11, p<0.01$, Sobel test $=2.603$, Aroian test $=$ 2.594 , Goodman test $=2.613$ ). Twenty percent of the influence was attributed to the indirect effect, and $80 \%$ to the direct effect.

Following Baron and Kenny's (1986) recommendations, we tested for significant variation between the independent and mediation variables, the mediation and dependent variables, and the independent and dependent variables. As presented in Table 6, all direct effects were significant. Moreover, we checked to determine whether the effect between the independent and dependent variables decreased when the mediator was included. The direct effect of open innovation on innovation performance decreased from $\beta=0.47(p<0.001)$ to $\beta=0.40(p<$ 
0.001); therefore, the mediation effect of absorptive capacity was supported. Our empirical results also indicated that the control variables technological turbulence and R\&D investment were significantly and positively related to the innovation performance of a firm. In particular, when technological changes in the industry increase, firms may opt to fight this uncertainty with a corresponding increase in product and/or process innovation. Moreover, firms that invest more in $\mathrm{R} \& \mathrm{D}$ introduce more product/service innovations.

In addition, we checked the robustness of the results on two subsamples (manufacturing vs. service firms) using multigroup comparison and found only one statistically significant difference among the subsamples; the subsamples differed only in the outsourcing of R\&D factor of the open innovation measure. Accordingly, the results indicated that manufacturing companies allocate more resources to $R \& D$ than service firms, which is in line with the literature that suggests that R\&D investment is mostly concentrated among manufacturing firms (e.g. Ehie/Olibe 2010).

\section{Table 6: Decomposition of effects among variables}

\begin{tabular}{lccc}
\hline & Total & Direct & Indirect \\
\hline No mediation & & & \\
Open innovation $\rightarrow$ Innovation & $0.47^{* * *}$ & $0.47^{* * *}$ & - \\
Technological turbulence $\rightarrow$ Innovation & $0.15^{* *}$ & $0.15^{* *}$ & \\
& & & - \\
Mediation & & $0.63^{* * *}$ & - \\
Open innovation $\rightarrow$ Absorptive capacity & $0.17^{* *}$ & $0.17^{* *}$ & $0.11^{* *}$ \\
Absorptive capacity $\rightarrow$ Innovation & $0.50^{* * *}$ & $0.40^{* * *}$ & $0.12^{*}$ \\
Open innovation $\rightarrow$ Innovation & $0.12^{*}$ & & \\
Technological turbulence $\rightarrow$ Innovation & &
\end{tabular}

Note. ${ }^{*}$ significant at $p<0.05 ;{ }^{* *}$ significant at $p<0.01 ;{ }^{* * *}$ significant at $p<0.001$

\section{Discussion and implications}

The research on open innovation has emerged over the past decade, and the body of knowledge on this important organisational phenomenon has grown, primarily in the context of the most developed European countries (i.e. EU15). Unfortunately, little is known about open innovation practices in companies in other parts of Europe. With our study, we aimed to expand the current knowledge by developing a conceptual model of open innovation and organisational performance, and testing it on an empirical sample of 421 companies from Slovenia. According to innovation scoreboard results (European Commission 2015), Slovenia offers a good case study opportunity among new and candidate members of the EU. 


\section{Figure 2: Results for the structural model (direct and indirect effects)}

H4: Proclivity for open innovation $\rightarrow$ Absorptive capacity $\rightarrow$ Innovation $+0.11^{* *}($ Sobel test $=2.603$, Aroian test $=2.594$, Goodman test $=2.613)$
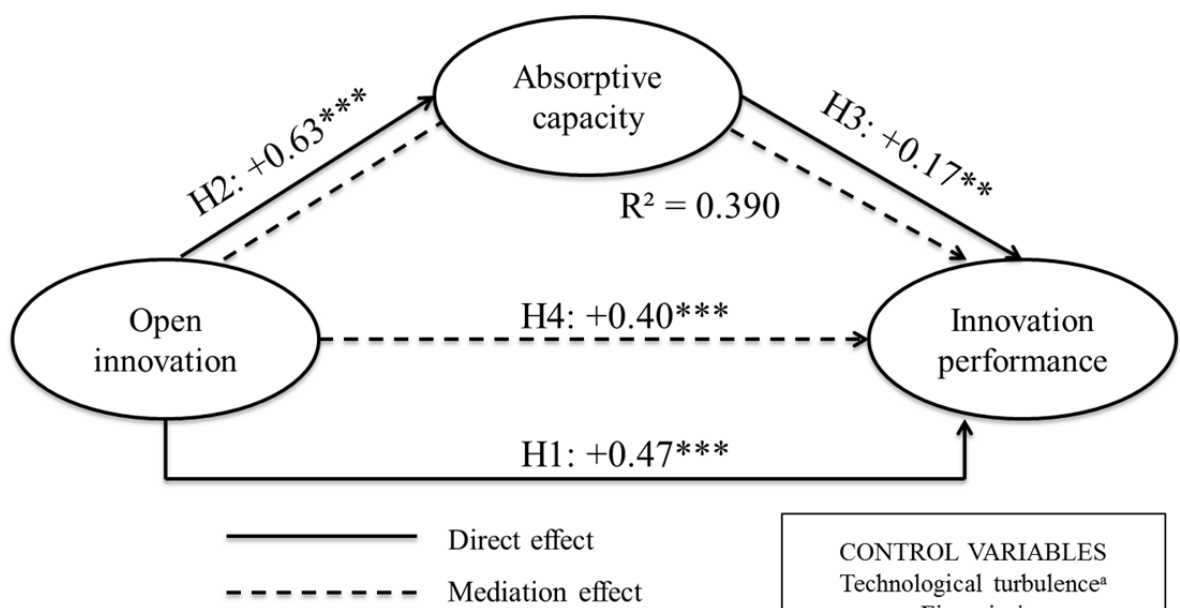

$*$ significant at $\mathrm{p}<0.05$

$* *$ significant at $\mathrm{p}<0.01$

$* * *$ significant at $\mathrm{p}<0.001$ a significant

${ }^{\mathrm{b}}$ non-significant

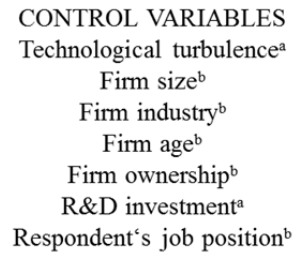

CONTROL VARIABLES

Technological turbulence ${ }^{a}$ Firm size ${ }^{b}$

Firm industry ${ }^{b}$ Firm age ${ }^{b}$

Firm ownership ${ }^{b}$ $R \& D$ investment

Respondent's job position ${ }^{b}$

Drawing on the resource-based view and dynamic capabilities perspective, the main objective of the paper was to conceptualise and empirically test a model of a firm's innovation performance and its key determinants - open innovation and absorptive capacity - in order to provide robust quantitative data on this important organisational correlate. We found that open innovation impacts innovation performance both directly and indirectly through absorptive capacity. Contrary to prior studies of open innovation, our model takes the multidimensionality of the constructs into account, incorporating the different dimensions and elements that embrace the complexity of innovation performance at the firm level. In doing so, we advance the literature on open innovation, which has often relied on anecdotal and qualitative representations of organisational open innovation. This study used a large dataset to empirically analyse mechanisms related to organisational capabilities that influence the relationship between open innovation and innovation performance. The results of the structural equation modelling supported our main hypothesis that absorptive capacity mediates the relationship between open innovation and innovation performance. 
As pointed out by scholars working on international comparisons of innovation systems (Schmoch et al. 2006; Fagerberg/Srholec 2008), most countries display idiosyncratic innovation behaviour, causing relations and outcomes to differ between variables. The literature on the country-specific organisation of innovation systems has summarised the key institutional aspects (Bergek et al. 2008). Spithoven (2013) revealed that the implicit suggestion of these macro- and meso-levels of innovation systems is that individual firms in each country exhibit the same underlying behaviour in terms of the innovation process. Since open innovation practices differ in firms as a function of their underlying aspects (e.g. size, industry, technological turbulence, and absorptive capacity), the general ecosystem exemplified by innovation systems impacts external firm-level relationships (Hekkert et al. 2007). By taking Slovenia as an example, we aimed to demonstrate that the institutional context affects open innovation relationships. Norms, values, and regulations all influence the innovation capabilities of actors in the system (Spithoven 2013). There has been some agreement over the fact that innovation capabilities are country-specific (Fagerberg/Srholec 2008). Globalisation processes, however, have been assumed to mitigate country differences to a certain extent (OECD 2008). Furthermore, the trend towards open innovation practices has also necessitated that the innovation capabilities of firms active in small countries like Slovenia be attuned to each other, since cross-border relationships are the rule. On the other hand, path dependency and lock-in effects make country differences more persistent (Spithoven 2013). Our empirical research provides several important contributions.

\subsection{Theoretical implications}

Our findings contribute to the existing literature on the role played by organisational capabilities in influencing a firm's innovation performance in several ways. First, this study complements the evidence that a firm's internal capabilities impact its innovation performance (Tsai 2001). Our main findings suggest that to be successful in innovation, organisations should open their innovation processes and nurture their absorptive capacity. While a considerable part of the literature in the field has focused on the direct effects of absorptive capacity on innovation performance or studied the moderating effects of absorptive capacity on the relationship between determinants and innovation performance, this study focused on understanding how absorptive capacity mediates the positive effects of open innovation on a firm's innovation performance. We contribute to the literature on absorptive capacity by providing evidence as to the antecedents of this capability, which can be triggered by a firm's open innovation (Fosfuri/ Tribó 2008). Moreover, we contribute to the work on open innovation, taking into consideration the multidimensional nature of the concept (Spithoven 2013). 
Second, in line with the resource-based view (Barney 1991), our study corroborates the importance attributed to internal resources for achieving superior innovation performance, especially in the form of employee involvement. Our research reveals that leveraging the knowledge of employees who are not involved in R\&D activities, collaborating across divisions, and searching for ideas inside and outside of the organisation facilitate innovation performance. In line with the extended resource-based view (Lavie 2006), our results support the salience of network resources in achieving and maintaining a firm's competitive position. We show that firms that are open towards innovation are embedded in different networks, maintain regular collaborations with various partners, and, in this way, leverage their knowledge and technology in ways that can enhance their innovation performance. Results from this study indicate that superior innovation performance can be achieved through networks established via external participation, outsourcing R\&D, and customer involvement.

\subsection{Managerial implications}

From a managerial point of view, our results emphasise the salience of networks as a bridge to the resources of other firms. Building and sustaining relationships with different partners can enable access to a broader set of resources and, in turn, positively influence innovation performance. Our study reports evidence that using external knowledge spurs innovation performance. Moreover, our study supports the argument that implementing open innovation requires harnessing additional internal strengths in order to fully impact innovation performance. It is not enough to open up the innovation process and search for external knowledge and ideas; firms have to possess the capabilities to modify and connect newly acquired knowledge with the existing knowledge base and to efficiently exploit it. If we generalise our findings, managers should bear in mind that a firm's capabilities are interconnected, and the stimulation of one capability may - positively or negatively - influence others.

Procter \& Gamble makes a good case in point. In the late 1990 s, the increasing cost of investments in R\&D, technology, and innovation and lower than expected sales growth triggered a shift in organisational culture towards one in which employees are stimulated to search for new ideas, to bring in external ideas, and to maintain enough flexibility in developing new products (Dodgson et al. 2006). By establishing the Connect \& Develop model as a tangible result of their new organisational culture, they boosted their knowledge stock and flow, contributing to both their improved absorptive capacity and more open innovation practices (Huston/Sakkab 2006). 


\subsection{Limitations and future research}

There are several limitations to this study, which open up possible avenues for future research. The first shortcoming of our research relates to the use of the proclivity for open innovation measure. Although the measure takes into consideration the multidimensional nature of the open innovation concept, it incorporates items that gauge a firm's inclination towards a specific activity, as well as items that evaluate the on-going open innovation-related activities of a firm. As such, in places, the scale measures the firm's tendency towards open innovation, rather than its actual open innovation activity. Nevertheless, according to Ajzen's (1991) theory of planned behaviour, a firm's intentions should be a good reflection of actual behaviour. An additional benefit of this measure is that it can be applied in the context of smaller firms, which, due to their small size and lack of capabilities, are unable to perform some open innovation activities (e.g. venturing); at the same time, they do not exhibit closed innovation mindsets. Second, the size distribution of the companies in the sample did not reflect the size distribution of the population of companies in Slovenia; the percentage of micro and smaller firms in our sample was lower than the percentage of such firms in the total population. On the other hand, our sample provided more equal representation of companies, which enabled comparison across groups (in terms of firm size). Comparing the companies in the sample with the total population, there were some differences (e.g. the percentage of services firms in our sample was higher than in the total population). However, we believe that the sample composition does not present a major concern for the paper as discussed under the section "Sampling and data collection." Third, our research design relied on the use of cross-sectional data, which somewhat limited our ability to infer causalities in the hypothesised relationships. Future research will profit from a longitudinal design. Fourth, the survey was conducted in a single national context. Hence, the replication of the model in other countries could deliver further insights and support the generalisability of the results, as mentioned in the first part of the discussion section. An interesting avenue for future research is the analysis of the role of organisational culture and structure in the relationship between open innovation and innovation performance. Finally, open innovation is not all about the organisational culture, structure, and management. Future studies should also include the role of individuals (top management as well as employees) in the model. An interesting topic might be a large-scale study examining how employees' willingness to change influences open innovation. For such a study, we suggest using a multi-level approach with cross-level interactions to examine the relationship between management style and open innovation in order to identify which managerial characteristics are the most important when implementing and integrating different open innovation activities. Furthermore, a multi-level approach incorporating organisational teams could show what kinds of team attributes are needed to support open innovation activities, how the use 
of external knowledge and technology influences innovation performance at the team level, and what kind of information is shared among members within and across teams.

Acknowledgement: Research financed in part by the European Union, European Social Fund.

\section{References}

Ajzen, I. (1991): The theory of planned behavior, in: Organizational Behavior and Human Decision Processes, 50, 2, 179-211.

Ambrosini, V./Bowman, C. (2009): What are dynamic capabilities and are they a useful construct in strategic management?, in: International Journal of Management Reviews, 11, 1, 29-49.

Barney, J.B. (1986): Organizational culture: Can it be a source of sustained competitive advantage?, in: Academy of Management Review, 11, 3, 656-665.

Barney, J.B. (1991): Firm resources and sustained competitive advantage, in: Journal of Management, 17, 1, 99-120.

Baron, R.M./Kenny, D.A. (1986): The moderator-mediator variable distinction in social psychological research: Conceptual, strategic, and statistical considerations, in: Journal of Personality and Social Psychology, 51, 6, 1173-1182.

Bergek, A./Jacobsson, S./Carlsson, B./Lindmark, S./Rickne, A. (2008): Analyzing the functional dynamics of technological innovation systems: A scheme of analysis, in: Research Policy, 37, 3, 407-429.

Block, Z./MacMillan, I. (1995): Corporate venturing: Creating new businesses within the firm. Boston: Harvard Business Press.

Bogliacino, F./Pianta, M. (forthcoming): The Pavitt taxonomy, revisited. Patterns of innovation in manufacturing and services, in: R\&D Management.

Chesbrough, H.W. (2003): Open innovation: The new imperative for creating and profiting from technology. Boston: Harvard Business Press.

Chesbrough, H.W. (2006): Open innovation: A new paradigm for understanding industrial innovation, in: Chesbrough, H.W./Vanhaverbeke, W./West, J. (eds.): Open innovation: Researching a new paradigm, Oxford: Oxford University Press, 1-12.

Chesbrough, H.W./Crowther, A.K. (2006): Beyond high tech: Early adopters of open innovation in other industries, in: R\&D Management, 36, 3, 229-236.

Cohen, W.M./Levinthal, D.A. (1989): Innovation and learning: The two faces of R\&D, in: The Economic Journal, 99, 397, 569-596.

Dillman, D.A./Smyth, J.D./Christian, L.M. (2009): Internet, mail, and mixed-mode surveys: The tailored design method. Hoboken: Wiley.

Dodgson, M./Gann, D./Salter, A. (2006): The role of technology in the shift towards open innovation: The case of Procter \& Gamble, in: R\&D Management, 36, 1, 333-346.

Dooley, L./Kenny, B./Cronin, M. (forthcoming): Interorganizational innovation across geographic and cognitive boundaries: Does firm size matter?, in: R\&D Management. 
Ehie, I.C./Olibe, K. (2010): The effect of R\&D investment on firm value: An examination of US manufacturing and service industries, in: International Journal of Production Economics, 128, 1, 127-135.

Eisenhardt, K.M./Martin, J.A. (2000): Dynamic capabilities: What are they?, in: Strategic Management Journal, 21, 10-11, 1105-1121.

European Commission. (2015). The Innovation Union Scoreboard 2015. http://ec.europa.eu/ enterprise/policies/innovation/policy/innovation-scoreboard/index_en.htm

Fabrizio, K.R. (2006): The use of university research in firm innovation, in: Chesbrough, H.W./Vanhaverbeke, W./West, J. (eds.): Open innovation: Researching a new paradigm, Oxford: Oxford University Press, 134-160.

Fagerberg, J./Srholec, M. (2008): National innovation systems, capabilities and economic development, in: Research Policy, 37, 9, 1417-1435.

Fosfuri, A./Tribó, J.A. (2008): Exploring the antecedents of potential absorptive capacity and its impact on innovation performance, in: Omega, 36, 2, 173-187.

Gassmann, O. (2006): Opening up the innovation process: Towards an agenda, in: R\&D Management, 36, 3, 223-228.

Hair, J.F./Black, W.C./Babin, B.J./Anderson, R.E./Tatham, R.L. (2010): Multivariate data analysis: A global perspective (Seventh ed.). Upper Saddle River, NJ: Pearson Education.

Hekkert, M.P./Suurs, R.A./Negro, S.O./Kuhlmann, S./Smits, R. (2007): Functions of innovation systems: A new approach for analysing technological change, in: Technological Forecasting and Social Change, 74, 4, 413-432.

Huizingh, E.K.R.E. (2011): Open innovation: State of the art and future perspectives, in: Technovation, 31, 1, 2-9.

Hurley, R.F./Hult, G.T.M. (1998): Innovation, market orientation, and organizational learning: An integration and empirical examination, in: Journal of Marketing, 62, 3, 42-54.

Huston, L./Sakkab, N. (2006): Connect and Develop: Inside Procter \& Gamble's new model for innovation, in: Harvard Business Review, 84, 3, 58-66.

Jaworski, B.J./Kohli, A.K. (1993): Market orientation: Antecedents and consequences, in: Journal of Marketing, 57, 53-70.

Jiménez-Jiménez, D./Sanz-Valle, R. (2011): Innovation, organizational learning, and performance, in: Journal of Business Research, 64, 4, 408-417.

Korsgaard, M.A./Roberson, L. (1995): Procedural justice in performance evaluation: The role of instrumental and non-instrumental voice in performance appraisal discussions, in: Journal of Management, 21, 4, 657-669.

Kotabe, M./Jiang, C.X./Murray, J.Y. (2011): Managerial ties, knowledge acquisition, realized absorptive capacity and new product market performance of emerging multinational companies: A case of China, in: Journal of World Business, 46, 2, 166-176.

Kraft, K. (1990): Are product and process innovations independent of each other?, in: Applied Economics, 22, 8, 1029-1038.

Krammer, S. (2009): Drivers of national innovation in transition: Evidence from a panel of Eastern European countries, in: Research Policy, 38, 5, 845-860.

Krapež, J./Škerlavaj, M./Groznik, A. (2012): Contextual variables of open innovation paradigm in the business environment of Slovenian companies, in: Economic and Business Review, 14, 1, 17-38. 
Laursen, K./Salter, A. (2006): Open for innovation: The role of openness in explaining innovation performance among UK manufacturing firms, in: Strategic Management Journal, 27, $2,131-150$.

Lavie, D. (2006): The competitive advantage of interconnected firms: An extension of the resource-based view, in: Academy of Management Review, 31, 3, 638-658.

Liao, S.-h./Fei, W.-C./Chen, C.-C. (2007): Knowledge sharing, absorptive capacity, and innovation capability: An empirical study of Taiwan's knowledge-intensive industries, in: Journal of Information Science, 33, 3, 340-359.

Meyer, K.E./Peng, M.W. (2005): Probing theoretically into Central and Eastern Europe: Transactions, resources, and institutions, in: Journal of International Business Studies, 36, $6,600-621$.

Mikl-Horke, G. (2004): Globalization, transformation and the diffusion of management innovations, in: Journal for East European Management Studies, 9, 2, 98-122.

Murrell, P. (1990): The nature of socialist economies: Lessons from Eastern European foreign trade: Princeton University Press Princeton, NJ.

O'Connor, G.C. (2005): Open, radical innovation: Toward an integrated model in large established firms, in: Chesbrough, H.W./Vanhaverbeke, W./West, J. (eds.): Open innovation: Researching a new paradigm, Oxford: Oxford University Press, 62-81.

OECD. (2008). Open innovation in global networks. Paris: OECD Publications.

Podsakoff, P.M./MacKenzie, S.B./Lee, J.-Y./Podsakoff, N.P. (2003): Common method biases in behavioral research: A critical review of the literature and recommended remedies, in: Journal of Applied Psychology, 88, 5, 879-903.

Rangus, K./Drnovšek, M. (2013): Open innovation in Slovenia: A comparative analysis of different firm sizes, in: Economic and Business Review, 15, 3, 175-196.

Rangus, K./Drnovšek, M./Di Minin, A. (2013). Proclivity for open innovation: Construct conceptualization and empirical validation. Paper presented at the Academy of Management, Orlando.

Rašković, M./Pustovrh, A./Dakić, M. (2011). Slovenska visokotehnološka mala in srednje velika podjetja na prepihu inovativne in razvojno tehnološke prebojnosti. Solkan: Cobik.

Santamaría, L./Nieto, M. J./Barge-Gil, A. (2009): Beyond formal R\&D: Taking advantage of other sources of innovation in low-and medium-technology industries, in: Research Policy, $38,3,507-517$.

Schmoch, U./Rammer, C./Legler, H. (eds.) (2006): National systems of innovation in comparison: Structure and performance indicators for knowledge societies. Dordrecht: Springer Science \& Business Media.

Schroll, A./Mild, A. (2011): Open innovation modes and the role of internal R\&D: An empirical study on open innovation adoption in Europe, in: European Journal of Innovation Management, 14, 4, 475-495.

Spithoven, A. (2013): Open innovation practices and innovative performances: An international comparative perspective, in: International Journal of Technology Management, 62, 1, $1-34$.

Tao, J./Magnotta, V. (2006): How air products and chemicals "identifies and accelerates", in: Research-Technology Management, 49, 5, 12-18. 
Teece, D.J. (2007): Explicating dynamic capabilities: The nature and microfoundations of (sustainable) enterprise performance, in: Strategic Management Journal, 28, 13, 13191350.

Teece, D.J./Pisano, G./Shuen, A. (1997): Dynamic capabilities and strategic management, in: Strategic Management Journal, 18, 7, 509-533.

Tether, B.S./Tajar, A. (2008): Beyond industry-university links: Sourcing knowledge for innovation from consultants, private research organisations and the public science-base, in: Research Policy, 37, 6-7, 1079-1095.

Tsai, W. (2001): Knowledge transfer in intraorganizational networks: Effects of network position and absorptive capacity on business unit innovation and performance, in: Academy of Management Journal, 44, 5, 996-1004.

Tünde, B./Gebert, D. (2005): Openness and innovation within organizations: An empirical analysis of the transformation process of Romanian enterprises, in: Journal for East European Management Studies, 10, 2, 107-130.

van de Vrande, V./de Jong, J.P.J./Vanhaverbeke, W./de Rochemont, M. (2009): Open innovation in SMEs: Trends, motives and management challenges, in: Technovation, 29, 6-7, 423-437.

Vanhaverbeke, W./Cloodt, M. (2014): Theories of the firm and open innovation, in: Chesbrough, H./Vanhaverbeke, W./West, J. (eds.): New frontiers in open innovation, Oxford: Oxford University Press, 256-278.

Wang, C.L./Ahmed, P.K. (2007): Dynamic capabilities: A review and research agenda, in: International Journal of Management Reviews, 9, 1, 31-51.

Zahra, S.A./George, G. (2002): Absorptive capacity: A review, reconceptualization, and extension, in: Academy of Management Review, 27, 2, 185-203.

Zhou, K.Z./Kin, C./Tse, D.K. (2005): The effects of strategic orientations on technology-and market-based breakthrough innovations, in: Journal of Marketing, 69, 2, 42-60. 


\section{APPENDIX}

\section{Items and standardised loadings of the final scales (based on the CFA)}

\begin{tabular}{|c|c|}
\hline \multirow{2}{*}{\multicolumn{2}{|c|}{$\begin{array}{l}\text { Scales } \\
\text { OI: INWARD IP LICENSING AND EXTERNAL PARTICIPATION (Rangus et al. 2013) }\end{array}$}} \\
\hline & \\
\hline (Strongly disagree/ Strongly agree) & 0.59 \\
\hline $\begin{array}{l}\text { We believe that investing in a new joint venture could result in new know-how/tech- } \\
\text { nology for our company. }\end{array}$ & 0.64 \\
\hline $\begin{array}{l}\text { We are willing to buy the intellectual property of other companies (e.g. patent, trade- } \\
\text { mark) to support our internal development. }\end{array}$ & 0.61 \\
\hline $\begin{array}{l}\text { We believe the use of know-how/technology from the outside can significantly con- } \\
\text { tribute to the innovation outcomes of our company. }\end{array}$ & 0.81 \\
\hline $\begin{array}{l}\text { We believe that know-how/technology we have bought can create new opportunities } \\
\text { for the company. }\end{array}$ & 0.83 \\
\hline We believe it is beneficial to determine systematic and formal ways of searching for & \\
\hline external know-how/technology. & 0.78 \\
\hline $\begin{array}{l}\text { To ensure successful development of new products/services, we usually buy the intel- } \\
\text { lectual property of other companies." }\end{array}$ & \\
\hline OI: OUTSOURCING R\&D AND EXTERNAL NETWORKING (Rangus et al. 2013) & \\
\hline (Never/Always) & 0.37 \\
\hline $\begin{array}{l}\text { In order to acquire new know-how/technology, we cooperate with knowledge institu- } \\
\text { tions such as universities, faculties, institutes, laboratories. }\end{array}$ & 0.75 \\
\hline $\begin{array}{l}\text { In order to acquire new know-how/technology, we cooperate with high-tech start-up } \\
\text { companies. }\end{array}$ & 0.59 \\
\hline $\begin{array}{l}\text { In order to acquire new know-how/technology, we cooperate with consultancy com- } \\
\text { panies.* }\end{array}$ & \\
\hline $\begin{array}{l}\text { We acquire new know-how/technology through research and development services } \\
\text { provided by knowledge institutions such as universities, faculties, institutes, laborato- }\end{array}$ & \\
\hline c & 0.84 \\
\hline $\begin{array}{l}\text { We acquire new know-how/technology through informal ties with researchers from } \\
\text { various laboratories. }\end{array}$ & 0.76 \\
\hline We acquire new know-how/technology through mentoring doctoral students. & 0.64 \\
\hline OI: CUSTOMER INVOLVEMENT (Rangus et al. 2013) & \\
\hline (Strongly disagree/ Strongly agree) & 0.50 \\
\hline $\begin{array}{l}\text { Our clients/end users are usually involved in the process of new product/service de- } \\
\text { velopment. }\end{array}$ & 0.78 \\
\hline $\begin{array}{l}\text { Our products/services are usually developed in light of customer/client wishes and } \\
\text { suggestions. }\end{array}$ & 0.72 \\
\hline In order to acquire new know-how/technology, we cooperate with our customers/ & \\
\hline clients. (Never/Always) & 0.55 \\
\hline OI: EMPLOYEE INVOLVEMENT (Rangus et al. 2013) & \\
\hline (Strongly disagree/Strongly agree) & 0.69 \\
\hline $\begin{array}{l}\text { When developing new ideas, we often consider the suggestions of employees not in- } \\
\text { cluded in the research and development process. }\end{array}$ & 0.65 \\
\hline $\begin{array}{l}\text { We actively encourage communication among unrelated groups of employees in the } \\
\text { company. }\end{array}$ & 0.74 \\
\hline e inform our employees about the importance of innovation to our bu & 0.72 \\
\hline $\begin{array}{l}\text { additionally award our employees if they bring external knc } \\
\text { at improves our products/services. }\end{array}$ & 0.68 \\
\hline
\end{tabular}

Note. $\mathrm{OI}=$ Open innovation

Items marked with * were excluded from the analysis. 
OI: VENTURING (Rangus et al. 2013)

(Strongly disagree/ Strongly agree)

When developing new activities related to the present operation of our company, we are willing to cooperate with the partners from the outside.

When developing new activities related to the present operation of our company, we use external sources of know-how/technology.

When launching our own new products/services on the market, we cooperate with external partners.

ABSORPTIVE CAPACITY (Kotabe et al. 2011)

(Strongly disagree/ Strongly agree)

We have the capability to adapt acquired new knowledge to fit the firm's development need.

We have the capability to develop new products/services by using assimilated new knowledge.*

We have the capability to develop new applications by applying assimilated new knowledge.

We have the capability to find alternative uses of assimilated new knowledge.

We have the capability to introduce product/service innovation based on acquired new knowledge.*

We have the capability to fuse assimilated new knowledge with existing knowledge. We have the capability to revise manufacturing/service processes based on acquired new knowledge.

We have the capability to revise business procedures based on acquired new knowledge.

We have the capability to revise quality control operations based on acquired new knowledge.

INNOVATION PERFORMANCE (Jiménez-Jiménez/Sanz-Valle 2011)

(Much worse than competitors/Much better than competitors)

In the last 3 years, our firm has performed worse/better than competitors in regard to the number of new products/services launched.

In the last 3 years, our firm has performed worse/better than competitors in regard to pioneering the introduction of new products/services (you were one of the first to introduce a new product/service).

In the last 3 years, our firm has performed worse/better than competitors in regard to the effort invested in the development of new products/services, taking into consideration the number of hours, people, teams and trainings.

In the last 3 years, our firm has performed worse/better than competitors in regard to the number of introduced changes in processes.

In the last 3 years, our firm has performed worse/better than competitors in regard to pioneering newly introduced processes (you've been one of the first to introduce new processes).

In the last 3 years, our firm has performed worse/better than competitors in regard to responding to new processes introduced by other companies in your field.

TECHNOLOGICAL TURBULENCE (Jaworski/ Kohli 1993)

(Strongly disagree/ Strongly agree)

The technology in our industry is changing rapidly.

Technological changes provide major opportunities in our industry.

A large number of new product/service ideas have been made possible through technological breakthroughs in our industry.

Technological developments in our industry are rather minor.*

Note. Ol = Open innovation

Items marked with * were excluded from the analysis. 